Bull. Fac. Agric., Cairo Univ., 71:145-156 (2020).

\title{
UTILIZATION OF WHEAT ALTERNATIVES TO PRODUCE FLAT BREAD WITH HIGH NUTRITIONAL VALUE
}

(Received:15.9.2020)

\author{
By \\ Hala H. Shaban, Ashgan M. Ali and M. Abo-Elnga \\ Department of Bread and Pasta Research, Food Technology Research Institute, \\ Agricultural Research Center, Giza, Egypt
}

\begin{abstract}
With the increase in urbanization and change in life style, there is a demand for convenience as well as nutritious food products, available within a short time. Hence, this investigation aimed to examine on various aspects of healthy multigrain whole meal to produce unleavened flat bread with new formulations with reference to economy and future scope. Multigrain unleavened flat bread was produced from whole meal barley or whole meal oat (40-60\%) with four different concentrations of corn (5-20\%); sorghum (5-15\%); rice flour (10\%) and wheat flour (20\%). Chemical composition, minerals, microbial load, texture and consumer acceptability were determined. There were significant differences between protein, crude fiber, ether extract, ash and the total carbohydrates contents of all produced bread blends as well as the control sample. All prepared bread had acceptable score values of taste, chewing ability, texture, aroma and color which were non- significantly different compared with the control bread. Minerals content increased by increasing oat and barley concentrations. Texture profile parameters (hardness, springiness, chewiness \& cohesiveness) increased by increasing the percentage of composite multigrain flours in the blends. All blends of oat and barley recorded the lowest values for total and yeast count (TBC and Y.C) during storage. Hence, high substitutions could considerably reduce the cost of raw materials and could nutritionally improve products with cereal blends.
\end{abstract}

Key words: Barley flour; oat flour; nutrition enriched; unleavened flat Bread

\section{INTRODUCTION}

The bread is usually prepared from a single coarse grain which was ground into a coarse powder. Although the exact date of origin of multigrain bread has not been documented, but indications point to the fact that the bread baked from a variety of grains was popular in most countries around the globe (Anonymous, 2011). Health beneficial effects of multigrain products are due to the incorporation of whole grain forms. Nutritional benefits are particularly enhanced when different whole grains, singly or in combination, are used in food preparation. Researches had shown that whole grain intake helps to lower the risk of cardiovascular disease, ischemic stroke, type 2 diabetes, metabolic syndrome, and gastrointestinal cancers (Jones, 2006). Cereal grains (barley, corn, maize, millet, oat, rice, rye, and sorghum) have always been the most important plant group for the human diet (Al-Dmoor, 2012). Whole grains are preferred as fiber present in outer bran part of the grain has many health benefits (phytochemicals) as phytoestrogens, phenolic compounds, antioxidants, phytic acid, folates, and vitamins (Dykes and Rooney, 2007; Dewettinck et al., 2008; Cavazos and Gonzalez de Mejia, 2013; and Belobrajdic and Bird, 2013). To enhance dietary fiber intake is necessary to fortify human foods with dietary fibers. Dietary fibers are polysaccharides of immense interest in nutrition and antioxidant. Currently, dietary fibers are incorporated in flour products, including cookies, bread, noodles, milk, and meat derived foods (Dhingra et al., 2012). Multigrain products strive to provide more of the essential micronutrients like $\mathrm{Fe}, \mathrm{Cu}, \mathrm{Mg}, \mathrm{Zn}$ and $\mathrm{Ca}$ compared to the individual grains. Iron participates in a wide variety of metabolic processes, including oxygen transport, DNA synthesis, and electron transport. However, iron concentrations in body tissues must be tightly regulated because excessive iron leads to tissue damage, as a result of formation 
of free radicals. On the other hand, deficiency of iron leads to anemia (Puntarulo, 2005; and Lieu et al., 2001).

Barley (Hordeum vulgare L.) is considered the fifth among all crops. Barley foods, like oat products, are an excellent source of beta-glucan soluble fiber. The beta-glucan content of wholegrain barley is equivalent to, or greater than that found in whole-grain oats. In a weight-for weight comparison, whole-grain barley is lower in fat, protein and calories and higher in total dietary fiber than whole-grain oats. Consumption of whole-grain barley products is consistent with the "2005 Dietary Guidelines for Americans" that recommend eating at least three servings of whole grains daily (Hidalgo et al., 2016; and U.S.D.H.S and U.S.D.A., 2005).

Oat is a rich source of soluble fiber, wellbalanced proteins and several vitamins and minerals essential for the human health, noting that $3.0 \mathrm{~g}$ of soluble fiber daily from these foods may reduce the risk of heart disease. Oat and barley (as a source of dietary fiber) were extensively studied in bakery products, and cookies (Mattila et al., 2005; and Han et al., 2017).

Maize 'Zea mays' is rich in energy and good quality protein but, the pericarp fraction, which contain $77.7-84.6 \%$ dietary fiber, adheres tightly to the outer surface of aleuron layer, so that, cannot be removed easily and become responsible for decreasing digestibility, smoothness of dough and finally, produce Fast staled bread (Krivanek et al., 2007).

Rice "Oryza sativa" is the second cereal crop in Egypt after wheat. The total produced quantities for wheat and rice were 9.46 and 5.72 million tons, respectively, in the year 2107 (Abdelaal and Thlmany, 2019). The nutritional contribution of rice flour goes to its content of amylase protein and low molecular weight sugar. Rice flour is gluten free and useful as alternative to wheat flour, which contains gluten that can cause celiac disease in susceptible individuals (Cho et al., 2014). A large quantity of broken rice grains result during the processing of rice which amount to 500.000 tons annually. Broken rice blend flour is also used to produce biscuits that are baked in microwave (Gonzalez-galan et al., 1991; Nammakuna et al., 2016 and Sirichokworrakit et al., 2015).

Sorghum (Sorghum bicolor) is an obligate cereal to Upper Egypt, where, climatic condition enable yield proliferation and people consume sorghum bread. A total of one million ton of sorghum grains is produced annually (Year Book of Agriculture Statistics, 2016). Besides providing calories, sorghum has actual nutritional value in principle, because of its content of protein, vitamins and minerals, such as iron, phosphorus and zinc and phenolic compound (Salazar-López et al., 2017; Chávez et al., 2017; De Cardoso et al., 2015; and AOSTAT, 2014). In composition, sorghum grain compares favorably with some other cereals as wheat, maize and rice (FAO, 1995; and Henley, 2010).

Flat breads are made throughout most of the world. Examples are tortilla, chapatti, pita, parotta, yufka, tandoori roti, sangak, balady, barbari, taftoon, lavas, ciabatta, baati, bafla, phulka, kulcha, gyro bread. Some flat bread has highly different characteristics rather than high volume pan bread (Coskuner et al., 1999).

The formulations of flat breads differ from region to region, but the basic ingredients are flour, water, salt (sodium chloride), and naturally fermented starter dough with either baking powder or baker's yeast. In addition, sugar, butter, vegetable shortening or non-fat dry milk may be added to enhance taste and aroma. The bread quality is only partly dependent on the quality parameters related to the raw material selected. The quality of bread is a complex concept influenced by many factors: quality of wheat, properties of flour and the baking procedures employed. Flour is the basic ingredient in a flat bread recipe as it affects the texture and sensory properties (Srivastava et al., 2002; Sharma et al., 1995; and Mondal and Datta, 2008). Freshly baked flat breads are soft and elastic, when kept at room temperature they stale within few hours and become hard and tough. For example; chapattis are generally prepared twice a day for lunch and dinner, and unless eaten immediately after preparation, they stale rapidly and become difficult to chew (Shalini and Laxmi, 2007). Multigrain breads are reported to have lot of health benefits. Multigrain bread introduce more fibre, vitamins and minerals in the diet than other types of bread (Angioloni and Collar, 2011).

In bakery products, spoilage caused by fungi is considered to be the greatest factor in limiting shelf-life and the major cause of economic losses in the bakery industry. The aerobic plate count (APC) and mould and yeast count (MYC) are the common methods used to confirm the safety of the food consumed by referring to the colony forming units (CFUs) 
counted in a sample(De Vuyst and Vancanneyt, 2007).

The introduction of flour types involved changes in bread formation properties as a result of composite flours. It is important to consider the contribution of the carbohydrates, proteins, and lipids from the involved grains. These components have vital effects on dough's rheological and physical properties (Marchetti et al., 2012).

Alternative non wheat cereals that has capacity to substitute wheat in bread flour in Egypt, includes barley, maize, rice and sorghum. Another very important point to consider from an economic point of view is that the price of wheat grain constantly fluctuates on international markets, so the objective of this study was to evaluate the physical and baking properties of whole oat and barley blends and the possibility of substituting with decorticated sorghum, broken rice, corn composite flours as well as to determine the organoleptic acceptability of the resulting breads, proximate analysis, minerals content and shelf life quality.

\section{MATERIALS AND METHODS}

\subsection{Materials}

Wheat flour ( $82 \%$ extraction rate); rice flour; corn flour; fenugreek powder and baking ingredients were obtained from local markets. White sorghum (Dorado variety) and naked barley (Hordeum vulgara L. Giza 131) samples were obtained from field Crops Institute, Agricultural Research Centre, Ministry of Agriculture, Giza, Egypt.

-Oat, corn flour, rice flour, fenugreek, sugar, oil, and salt were obtained from the local market.

\subsection{Methods}

\subsubsection{Preparation of samples}

Barley, oat and sorghum samples were carefully cleaned to be free from broken grains and extraneous matter. All grains were conditioned to $14 \%$ moisture content for $16 \mathrm{~h}$ and milled using fractionation Laboratory mill (Brabender Duisburg roller mill, Germany) to obtain fine flour (whole meal).

Flat bread was prepared with modification according to the method described by Shobha $e t$ al.,(2008). Flat bread formulas used are showed in Table (1). Flour and other ingredients were mixed carefully, then water was added and kneaded well to make soft dough of uniform consistency and were rest for (20-30min) before baking. The dough was divided into small balls $(50 \mathrm{~g})$, and flattened on a hard wooden surface sprinkled with a small quantity of flour. Bread loaf baked for 1 to 2 min for both sides on hot griddle drizzled with little oil. The prepared breads were cooled and then packed in polyethylene bags until further analysis.

\subsubsection{Chemical analysis}

Moisture, protein, fats, crude fiber and ash contents of the raw materials and bread samples were determined according to the methods of AOAC (2005). Total carbohydrates was calculated by difference.

\subsubsection{Determination of minerals}

Bread sample $(2 \mathrm{~g})$ was weighed and heated at $550^{\circ} \mathrm{C}$. Then the ashes were dissolved with $100 \mathrm{ml} \mathrm{HCl}(1 \mathrm{M})$ using method of AOAC (2005). Perkin Elmer (Model 3300, USA) Atomic Absorption Spectrophotometer was used to determine $\mathrm{Na}, \mathrm{K}, \mathrm{Ca}, \mathrm{Fe}, \mathrm{P}, \mathrm{Mg}, \mathrm{Mn}, \mathrm{Cu}$ and $\mathrm{Zn}$ in bread samples.

\subsubsection{Organoleptic evaluation of flat bread}

Flat bread samples were evaluated organolyptically for its sensory characteristics. Half slice of each bread sample was served for ten panelists to evaluate taste, chewing ability, texture, aroma and color using a score from 1 to 10. The evaluation was conducted by ten persons on the basis of a ten-point score according to the method of Land and Shepherd, (1988).

Table (1): Formulas of barley/ oat blends used for production unleavened flat bread.

\begin{tabular}{|c|c|c|c|c|c|c|c|c|c|}
\hline \multirow[t]{2}{*}{ Ingredients } & \multicolumn{4}{|c|}{ Barley blend (g/100g) } & \multicolumn{4}{|c|}{ Oat blend (g/100g) } & \multirow[t]{2}{*}{ Control blend } \\
\hline & B1 & B2 & B3 & B4 & O1 & $\mathbf{O 2}$ & $\mathbf{O 3}$ & O4 & \\
\hline Barley/Oat flour & 40 & 40 & 50 & 60 & 40 & 40 & 50 & 60 & - \\
\hline Corn flour & 20 & 15 & 10 & 5 & 20 & 15 & 10 & 5 & - \\
\hline Sorghum flour & 10 & 15 & 10 & 5 & 10 & 15 & 10 & 5 & - \\
\hline Wheat flour & 20 & 20 & 20 & 20 & 20 & 20 & 20 & 20 & 100 \\
\hline Rice flour & 10 & 10 & 10 & 10 & 10 & 10 & 10 & 10 & - \\
\hline Fenugreek powder & 1 & 1 & 1 & 1 & 1 & 1 & 1 & 1 & 1 \\
\hline Sugar & 1 & 1 & 1 & 1 & 1 & 1 & 1 & 1 & 1 \\
\hline Oil & 7 & 7 & 7 & 7 & 7 & 7 & 7 & 7 & 7 \\
\hline Salt & 1 & 1 & 1 & 1 & 1 & 1 & 1 & 1 & 1 \\
\hline Water & 75 & 75 & 75 & 75 & 75 & 75 & 75 & 75 & 75 \\
\hline
\end{tabular}




\subsubsection{Texture analysis}

Texture analyzer (Brookfield CT3 No. M08-372-C0113, USA) was used to measure the texture profile of flat bread at zero time and during storage in terms of hardness $(\mathrm{N})$, adhesiveness (mj), springiness (mm) and resilience of the samples according to the method described by Gomez et al., (2007).

\subsubsection{Microbiological analysis}

Microbiological analysis (Total bacteria count: (TBC); and Yeast count: (YC) was carried out as described by Gul et al., (2005).

\subsubsection{Statistical analysis}

Data were statically analyzed using MSTAT-C v.2.1 (Michigan State University, Michigan, USA) and mean comparisons were based on the least significant difference (LSD at 5\%) test according to Maxwell and Delaney, (1989).

\section{RESULTS AND DISCUSSION}

3.1. Chemical composition of the mixture of different flour blends

Results of the chemical composition of the mixture of different flour blends are presented in Table (2).

Data showed that protein, crude fiber, ether for control sample. The obtained results were agreement with Sobczylc, (2008) who mentioned that oat cultivars had high nutritive value due to the high content of total protein (from 14.4 to $19.4 \%$ ). Malik et al., (2015) showed that the carbohydrate content of different flours (wheat, barley, oat, corn and rice) used in the development of multigrain bread varied from $62 \%$ (oat) to $76 \%$ (rice). However the carbohydrate content of wheat and barley were significantly the same. The protein content varied from 6.77 in rice to $11.65 \%$ in barley. The fat content varied from 0.51 (wheat) to $4.58 \%$ (maize), although the percentage of fat is significantly same in oats and maize but differ from other flours. The highest fiber content was found in barley $(6.75 \%)$ and the lowest was found in rice $(0.62 \%)$, while ash content varied from $0.66 \%$ (wheat) to $2.2 \%$ (barley). Similar results were reported by Dhingra and Jood, (2004).

\subsection{Sensory evaluation of unleavened flat bread blends}

The sensory attributes one of the limiting factors for consumer acceptability, so taste, chewing ability, texture, aroma and color were evaluated. Sensory evaluation results of flat

Table (2): Chemical composition of flour formulas of barley/ oat blends ( $\mathrm{g} / 100 \mathrm{~g}$ ) as dry weight basis.

\begin{tabular}{|c|c|c|c|c|c|c|}
\hline \multicolumn{2}{|c|}{ Sample } & Protein & Crude Fiber & Ether extract & Ash & Total \\
\hline \multicolumn{2}{|c|}{ Control (Wheat 82\%) } & $\mathbf{1 3 . 6 0} \pm 0.05^{\mathrm{a}}$ & $1.66 \pm 0.05^{\mathrm{ab}}$ & $1.51 \pm 0.01^{a b}$ & $1.55 \pm 0.05^{\mathrm{a}}$ & $81.68 \pm 0.08^{\mathrm{ab}}$ \\
\hline \multirow{4}{*}{$\begin{array}{c}\text { Barley } \\
\text { Samples }\end{array}$} & B1 & $13.35 \pm 0.10^{\mathrm{ab}}$ & $3.00 \pm 0.05^{\mathrm{a}}$ & $2.10 \pm 0.05^{\mathrm{a}}$ & $1.35 \pm 0.03^{\mathrm{ab}}$ & $80.20 \pm 0.11^{\mathrm{a}}$ \\
\hline & B2 & $13.56 \pm 0.04^{\mathrm{a}}$ & $3.45 \pm 0.09^{\mathrm{a}}$ & $2.00 \pm 0.02^{\mathrm{a}}$ & $1.40 \pm 0.06^{\mathrm{a}}$ & $79.59 \pm 0.13^{\mathrm{a}}$ \\
\hline & B3 & $13.86 \pm 0.09^{\mathrm{a}}$ & $3.91 \pm 0.03^{\mathrm{a}}$ & $1.85 \pm 0.03^{\mathrm{a}}$ & $1.51 \pm 0.08^{\mathrm{a}}$ & $78.87 \pm 0.10^{\mathrm{a}}$ \\
\hline & B4 & $13.99 \pm 0.05^{\mathrm{a}}$ & $3.98 \pm 0.13^{\mathrm{a}}$ & $1.67 \pm 0.04^{\mathrm{ab}}$ & $1.63 \pm 0.06^{\mathrm{a}}$ & $78.73 \pm 0.10^{\mathrm{a}}$ \\
\hline \multicolumn{2}{|c|}{ L.S.D ${ }_{0.05}$} & 0.44 & 1.51 & 0.38 & 0.21 & 1.86 \\
\hline \multirow{4}{*}{$\begin{array}{c}\text { Oat } \\
\text { Samples }\end{array}$} & 01 & $13.34 \pm 0.10^{\mathrm{ab}}$ & $2.89^{\mathrm{a}} \pm 0.07$ & $1.87 \pm 0.02^{\mathrm{a}}$ & $1.42 \pm 0.07^{\mathrm{ab}}$ & $80.48 \pm 0.10^{\mathrm{a}}$ \\
\hline & O2 & $13.51 \pm 0.06^{\mathrm{ab}}$ & $3.23 \pm 0.13^{\mathrm{a}}$ & $1.81 \pm 0.06^{\mathrm{a}}$ & $1.50 \pm 0.06^{\mathrm{ab}}$ & $79.95 \pm 0.15^{\mathrm{a}}$ \\
\hline & $\mathbf{O 3}$ & $13.84 \pm 0.08^{\mathrm{a}}$ & $3.84 \pm 0.08^{\mathrm{a}}$ & $1.80 \pm 0.04^{\mathrm{a}}$ & $1.68 \pm 0.06^{\mathrm{a}}$ & $78.84 \pm 0.12^{\mathrm{a}}$ \\
\hline & 04 & $13.95 \pm 0.09^{\mathrm{a}}$ & $3.95 \pm 0.09^{\mathrm{a}}$ & $1.73 \pm 0.04^{\mathrm{a}}$ & $1.75 \pm 0.05^{\mathrm{a}}$ & $78.62 \pm 0.13^{\mathrm{a}}$ \\
\hline \multicolumn{2}{|c|}{ L.S.D 095} & 0.43 & 1.47 & 0.24 & 0.24 & 1.94 \\
\hline
\end{tabular}

Means in the same column with different letters are significantly different $(p \leq 0.05)$, each mean value is followed by $\pm \mathrm{SE}$ (standard error)

*calculated by difference $[100-($ Protein + ash+ ether extract +Crude Fiber $)]$

extract, ash and total carbohydrates contents of all produced bread blends as well as the control sample were significantly the same, since protein content varied from $13.34 \%$ for $\mathrm{O} 1$ sample to $13.99 \%$ for B4 sample, crude fiber content varied from $1.66 \%$ for control sample to $3.98 \%$ for B4 sample, ether extract varied from $1.51 \%$ for control sample to $2.10 \%$ for B1 sample, ash varied from $1.35 \%$ for B1 sample to $1.75 \%$ for $\mathrm{O} 4$ sample and total carbohydrates varied from $78.62 \%$ for $\mathrm{O} 4$ sample to $81.58 \%$ bread produced from various multigrain composite flours displayed in eight different blends (four barley blends B1-B4 and four oat blends O1-O4) were shown in Tables (3 and 4) and Fig. (1).

It is obvious that all bread had acceptable values for taste comparing with the control bread samples except $\mathrm{O} 1$ bread (40\%oat+20\% wheat $+10 \%$ rice $+20 \%$ corn $+10 \%$ sorghum). 
Table (3): Sensory evaluation of unleavened flat bread blends .

\begin{tabular}{|c|l|l|l|c|c|}
\hline Sample & Taste & Chewing ability & Texture & Aroma & Color \\
\hline Control (Wheat 82\%) & $8.85 \pm 0.07^{\mathrm{b}}$ & $9.15 \pm 0.16^{\mathrm{a}}$ & $9.15 \pm 0.15^{\mathrm{a}}$ & $9.15 \pm 0.15^{\mathrm{a}}$ & $9.05 \pm 0.15^{\mathrm{a}}$ \\
\hline O1 & $8.50 \pm 0.07^{\mathrm{b}}$ & $8.90 \pm 0.20^{\mathrm{b}}$ & $8.95 \pm .20^{\mathrm{ab}}$ & $8.95 \pm 0.18^{\mathrm{b}}$ & $8.7 \pm 0.23^{\mathrm{ab}}$ \\
\hline O2 & $9.05 \pm 0.17^{\mathrm{ab}}$ & $8.95 \pm 0.22^{\mathrm{ab}}$ & $9.3 \pm 0.20^{\mathrm{a}}$ & $9.15 \pm 0.18^{\mathrm{a}}$ & $8.85 \pm 0.19^{\mathrm{ab}}$ \\
\hline O3 & $9.45 \pm 0.11^{\mathrm{a}}$ & $9.4 \pm 0.12^{\mathrm{a}}$ & $9.2 \pm 0.08^{\mathrm{a}}$ & $9.6 \pm 0.12^{\mathrm{a}}$ & $9.35 \pm 0.13^{\mathrm{a}}$ \\
\hline O4 $_{\text {L.S.D }}^{\mathbf{0 . 0 5}}$ & $9.65 \pm 0.10^{\mathrm{a}}$ & $9.7 \pm 0.13^{\mathrm{a}}$ & $9.6 \pm 0.12^{\mathrm{a}}$ & $9.65 \pm 0.13^{\mathrm{a}}$ & $9.6 \pm 0.12^{\mathrm{a}}$ \\
\hline
\end{tabular}

Means in the same column with different letters are significantly different $(p \leq 0.05)$.

Each mean value is followed by $\pm \mathrm{SE}$ (standard error).

Table (4): Sensory evaluation of unleavened bread blends.

\begin{tabular}{|c|c|c|c|c|c|}
\hline Sample & Taste & Chewing ability & Texture & Aroma & Color \\
\hline Control (Wheat 82\%) & $8.85 \pm 0.07^{\mathrm{ab}}$ & $9.15 \pm 0.16^{\mathrm{a}}$ & $9.15 \pm 0.15^{\mathrm{a}}$ & $9.15 \pm 0.15^{\mathrm{a}}$ & $9.05 \pm 0.15^{\mathrm{a}}$ \\
\hline B1 & $8.35 \pm 0.15^{\mathrm{b}}$ & $8.65 \pm 0.13^{\mathrm{ab}}$ & $8.40 \pm 0.12^{\mathrm{b}}$ & $8.70 \pm 0.18^{\mathrm{ab}}$ & $8.85 \pm 0.22^{\mathrm{ab}}$ \\
\hline B2 & $8.65 \pm 0.10^{\mathrm{b}}$ & $8.85 \pm 0.15^{\mathrm{ab}}$ & $8.50 \pm 0.10^{\mathrm{ab}}$ & $8.85 \pm 0.10^{\mathrm{ab}}$ & $9.20 \pm 0.13^{\mathrm{a}}$ \\
\hline B3 & $9.50 \pm 0.12^{\mathrm{a}}$ & $8.60 \pm 0.12^{\mathrm{b}}$ & $9.55 \pm 0.13^{\mathrm{a}}$ & $9.50 \pm 0.12^{\mathrm{a}}$ & $9.50 \pm 0.12^{\mathrm{a}}$ \\
\hline B4 $_{\text {L.S.D }}^{\mathbf{0 . 0 5}}$ & $9.65 \pm 0.13^{\mathrm{a}}$ & $9.50 \pm 0.12^{\mathrm{a}}$ & $9.60 \pm 0.12^{\mathrm{a}}$ & $9.61 \pm 0.12^{\mathrm{a}}$ & $9.50 \pm 0.10^{\mathrm{a}}$ \\
\hline
\end{tabular}

Means in the same column with different letters are significantly different ( $p \leq 0.05)$. Each mean value is followed by \pm SE (standard error).

Chewing ability, texture and aroma values showed no significant differences compared with control bread except $\mathrm{O} 1$ bread for chewing ability and aroma. There is no significant difference between different bread samples in color compared with wheat control bread. Moreover, colors in bread samples prepared with high percentage of oat were very close to those of the control bread. These results were in agreement with Dhore, (2011), who reported that the appearance of the bread fortified with $20 \%$ soya bean flour with sorghum was superior for texture. The texture, flavor, taste, appearance, mouth feel and overall acceptability had no-significant differences with the treatment groups. In contrast Abdelghafor et al., (2011) reported that the general appearance of balady bread was significantly different with increasing levels of sorghum flours (whole/ decorticated). Overall bread quality at the different levels of added whole and decorticated sorghum flours was found to be acceptable. However, acceptability increased as the level of sorghum flour, decorticated or whole, decreased.

Sensory evaluation results of barley bread were shown in Table 4 . The addition of barley flour showed no significant differences for the aroma or color of bread. Also, the results for texture and chewing ability were very close to those of wheat control bread. While, B1 and B3 bread recorded significant differences compared with the control bread. Finally, more addition of barley and oat percentages led to more acceptable bread. In contrast Wani et al., (2016) reported that sensory evaluation of flat bread produced from wheat-pulse composite flours showed significant decrease in color, taste, aroma, breakability, and overall acceptability scores at $15 \%$ replacement or higher. Gupta, et al., (2011) and Malik et al., (2015) reported that the texture of the bread is related to external hardness or softness of bread. The texture is the quality of bread that can be decided by touch, the degree to which it is rough or smooth, hard or soft. Also, these results are similar to the one reported by Sanful and Darko, (2010). The flavor of the bread refers to its palatability. Also the score for flavor ranged from 6.8 to 7.2 . It is evident from data that the difference in flavor values could be due to the incorporation of maize flour in the multigrain bread samples. Higher the amount of oat and barley added in the samples more is the undesirable flavor Gupta, et al., (2011).

\subsection{Minerals content of unleavened flat bread blends}

Minerals content of all prepared breads was determined and listed in Table (5).

The results indicated that $\mathrm{Fe}$ values of barley and oat bread varied from 54.4 to 79.1 and from 57.12 to $95.7 \mathrm{mg} / \mathrm{kg}$, respectively. Bread supplemented with oat flour had the highest content of $\mathrm{Fe}, \mathrm{Ca}, \mathrm{Cu}$ and $\mathrm{P}$ content compared with barley and wheat bread and the values increased gradually with increasing the addition of oat. From the same results, it could be noticed 


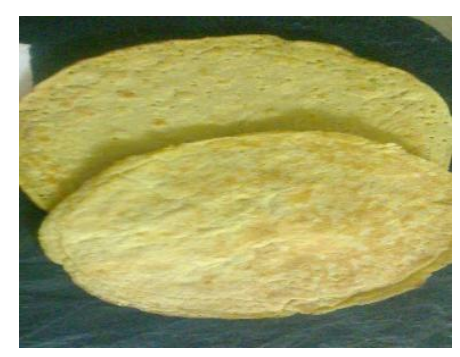

Control*

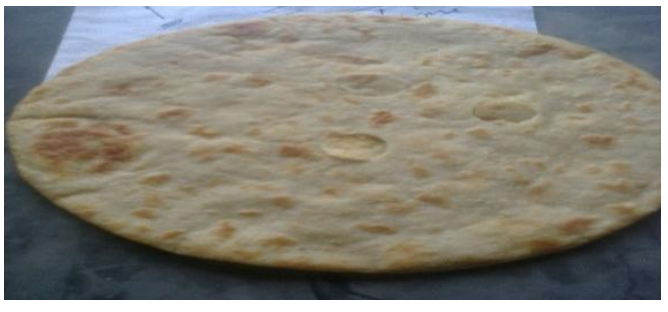

B1

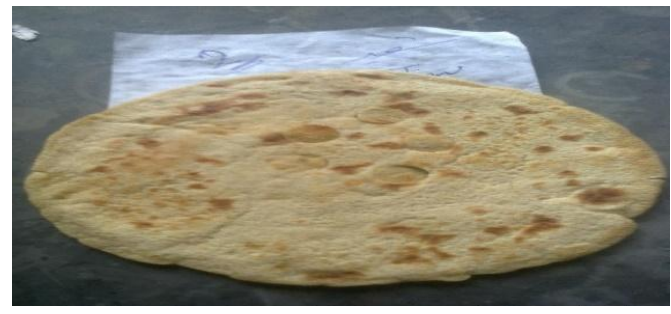

B2

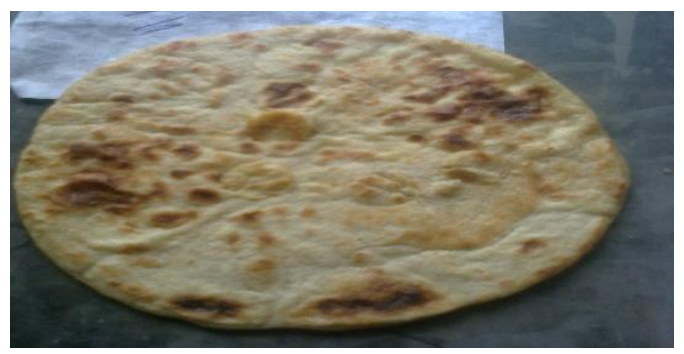

B3

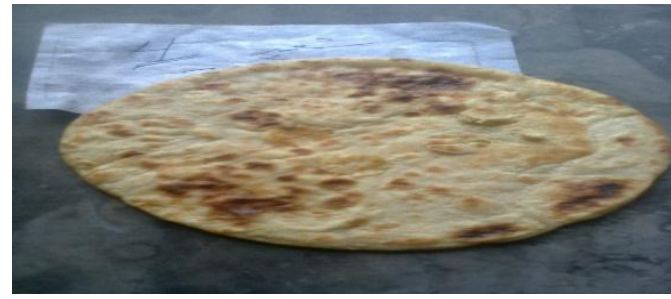

B4

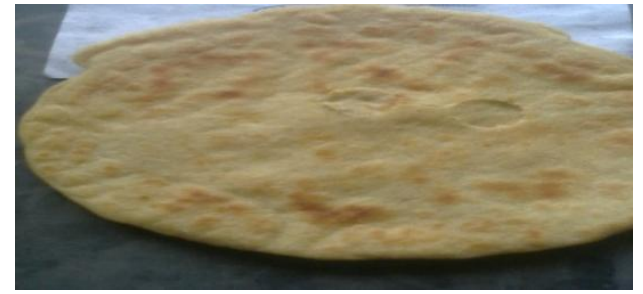

01

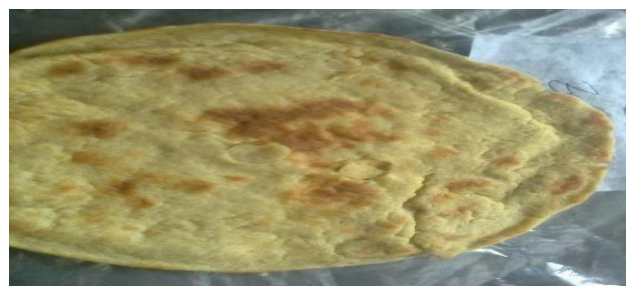

O2

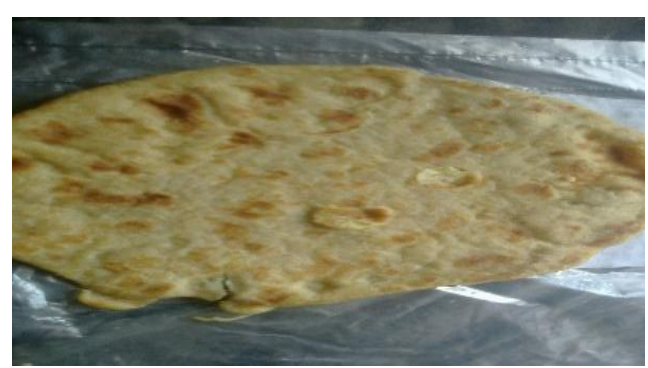

03

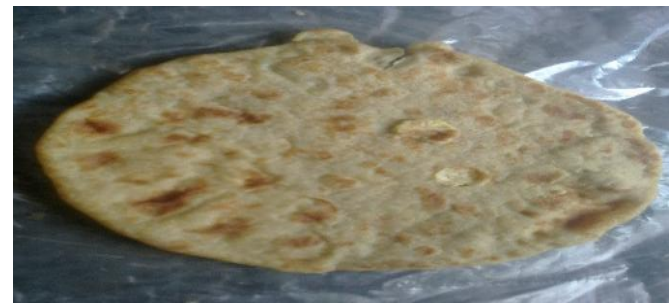

O4

Fig.(1): Unleavened flat bread made using barley/oat and control bread (wheat flour $82 \%$ ex. rate. 
Table (5): Minerals content of unleavened flat bread blends (ppm).

\begin{tabular}{|c|c|c|c|c|c|c|c|c|c|}
\hline \multirow{2}{*}{ Minerals } & \multirow{2}{*}{$\begin{array}{c}\text { Control } \\
\text { (Wheat } \\
82 \% \text { ) }\end{array}$} & \multicolumn{4}{|c|}{ Barley Samples } & \multicolumn{4}{|c|}{ Oat Samples } \\
\hline & & B1 & B2 & $\mathbf{B 3}$ & B4 & 01 & $\mathbf{O 2}$ & $\mathbf{O 3}$ & 04 \\
\hline $\mathbf{N a}$ & 20360 & 18477 & 18521 & 19100 & 19516 & 17748 & 17813 & 17915 & 17980 \\
\hline $\mathbf{K}$ & 14880 & 15238 & 15907 & 15530 & 15424 & 13431 & 13501 & 13485 & 13466 \\
\hline $\mathbf{C a}$ & 144 & 140 & 162 & 166 & 171 & 159 & 165 & 170 & 178 \\
\hline $\mathbf{F e}$ & 43.36 & 54.4 & 62.7 & 69.3 & 79.1 & 57.12 & 61.12 & 86.31 & 95.7 \\
\hline $\mathbf{P}$ & 877.1 & 880.0 & 928.2 & 1167.0 & 1230.4 & 1158.4 & 1267.3 & 1492.1 & 1514.5 \\
\hline Mg & 645.1 & 668.8 & 858.5 & 913.8 & 1006.0 & 934.7 & 1113.1 & 1290.6 & 1380.2 \\
\hline Mn & 54.12 & 57.35 & 58.5 & 64.44 & 88.44 & 81.83 & 84.16 & 86.41 & 89.15 \\
\hline $\mathbf{C u}$ & 23.98 & 31.22 & 32.25 & 38.15 & 39.88 & 48.21 & 49.11 & 50.80 & 51.11 \\
\hline Zn & 44.15 & 64.12 & 64.33 & 65.16 & 66.11 & 54.51 & 54.66 & 56.78 & 57.58 \\
\hline
\end{tabular}

that $\mathrm{K}$ content was higher in barley bread, while it was lower in oat bread. While the control wheat bread showed highest $\mathrm{Na}$ content compared with oat and barley bread. Minerals are vital to the functioning of many body processes. They are critical players in the functioning of the nervous system, other cellular processes, water balance and structural (e.g. skeletal) systems (Ameh et al., 2013). Inadequate intakes of micronutrients (minerals) have been associated with severe malnutrition, increased disease conditions and mental impairment (Shubhangini, 2002; and Abulude, 2005).

\subsection{Chemical composition of unleavened flat} bread blends

The chemical composition of unleavened flat bread is present in Table (6).

The protein, fat, and ash contents were obviously increased in formula (O4) compared with control. Protein, fat and ash content were $13.73,8.80$ and $2.48 \%$ in $\mathrm{O} 4$ and $(13.20,7.56$, and 1.75) in control sample, respectively. On the other hand, a slight decrease in carbohydrate contents was noticed in the same sample (O4). There were slight increases in ether extract in oat and barley flat bread samples, while a carbohydrate contents decreased gradually by increasing blends percentage. A noticeable increase in crude fiber and ash contents in both of oat and barley flat bread samples. The protein content and ether extract in barley bread samples were slightly lower than oat bread samples. While, crude fiber and ash content in oat were slightly lower than in barley bread samples.

Malik et al., (2015) reported that protein content of various multigrain bread varied from $6.00 \%$ to $8.40 \%$, similar results were reported by Sanful and Darko (2010). Also Malik et al., (2015) showed that the minimum value of fat content $(2 \%)$ and the maximum value was (4.6 $\%)$ in various multigrain bread samples. The highest amount of fiber was $(16 \%)$ while the lowest amount was $(10 \%)$. The same results were observed by Malolma et al., (2011). The difference in the fiber content could be due to the presence of high amount of oat and barley present in different multigrain bread samples.

Table (6): Chemical composition of unleavened flat bread blends (g/100g) as dry weight basis.

\begin{tabular}{|c|c|c|c|c|c|c|c|}
\hline \multicolumn{2}{|c|}{ Sample } & Protein & Crude Fiber & $\begin{array}{c}\text { Ether } \\
\text { Extract } \\
\end{array}$ & Ash & $\begin{array}{c}\text { Total } \\
\text { Carbohydrate* }\end{array}$ & Moisture \\
\hline \multicolumn{2}{|c|}{$\begin{array}{c}\text { Control (Wheat } \\
82 \% \text { ) } \\
\end{array}$} & $13.20 \pm 0.05^{\mathrm{a}}$ & $1.86 \pm 0.04^{\mathrm{ab}}$ & $7.56 \pm 0.09^{\mathrm{ab}}$ & $1.75 \pm 0.03^{\mathrm{ab}}$ & $75.63 \pm 0.08^{\mathrm{a}}$ & $37.21 \pm 0.10^{b}$ \\
\hline \multirow{4}{*}{$\begin{array}{c}\text { Barley } \\
\text { Samples }\end{array}$} & B1 & $12.86 \pm 0.07^{\mathrm{ab}}$ & $3.17 \pm 0.04^{\mathrm{a}}$ & $8.10 \pm 0.07^{\mathrm{a}}$ & $1.85 \pm 0.05^{\mathrm{ab}}$ & $74.02 \pm 0.09^{\mathrm{a}}$ & $38.27 \pm 0.04^{\mathrm{a}}$ \\
\hline & $\overline{\text { B2 }}$ & $13.15 \pm 0.005^{\mathrm{a}}$ & $3.60 \pm 0.04^{\mathrm{a}}$ & $8.42 \pm 0.09^{\mathrm{a}}$ & $1.89 \pm 0.05^{\mathrm{ab}}$ & $72.94 \pm 0.07^{\mathrm{a}}$ & $38.36 \pm 0.08^{\mathrm{a}}$ \\
\hline & B3 & $13.57 \pm 0.05^{\mathrm{a}}$ & $4.76 \pm 0.19^{\mathrm{a}}$ & $8.65 \pm 0.09^{\mathrm{a}}$ & $2.30 \pm 0.08^{\mathrm{a}}$ & $70.72 \pm 0.13^{\mathrm{a}}$ & $38.45 \pm 0.04^{\mathrm{a}}$ \\
\hline & B4 & $13.68 \pm 0.04^{\mathrm{a}}$ & $4.79 \pm 0.13^{\mathrm{a}}$ & $8.77 \pm 0.04^{\mathrm{a}}$ & $2.60 \pm 0.06^{\mathrm{a}}$ & $70.16 \pm 0.14^{\mathrm{a}}$ & $38.67 \pm 0.08^{\mathrm{a}}$ \\
\hline \multicolumn{2}{|c|}{ L.S.D ${ }_{0.05}$} & 0.54 & 1.97 & 0.87 & 0.59 & 3.65 & 0.93 \\
\hline \multirow{4}{*}{$\begin{array}{c}\text { Oat } \\
\text { Samples }\end{array}$} & O1 & $12.88 \pm 0.10^{b}$ & $3.35 \pm 0.04^{\mathrm{a}}$ & $8.16 \pm 0.04^{\mathrm{a}}$ & $2.00 \pm 0.06^{\mathrm{a}}$ & $73.61 \pm 0.06^{\mathrm{a}}$ & $38.92 \pm 0.10^{\mathrm{a}}$ \\
\hline & $\mathbf{O 2}$ & $13.05 \pm 0.06^{\mathrm{ab}}$ & $3.53 \pm 0.04^{\mathrm{a}}$ & $8.52 \pm 0.07^{\mathrm{a}}$ & $2.18 \pm 0.10^{\mathrm{a}}$ & $72.72 \pm 0.16^{\mathrm{a}}$ & $38.99 \pm 0.10^{\mathrm{a}}$ \\
\hline & $\mathbf{O 3}$ & $13.52 \pm 0.02^{\mathrm{a}}$ & $4.14 \pm 0.04^{\mathrm{a}}$ & $8.68 \pm 0.10^{\mathrm{a}}$ & $2.25 \pm 0.09^{\mathrm{a}}$ & $71.41 \pm 0.16^{\mathrm{a}}$ & $39.06 \pm 0.04^{\mathrm{a}}$ \\
\hline & O4 & $13.73 \pm 0.09^{\mathrm{a}}$ & $4.35 \pm 0.04^{\mathrm{a}}$ & $8.80 \pm 0.08^{\mathrm{a}}$ & $2.48 \pm 0.08^{\mathrm{a}}$ & $70.64 \pm 0.08^{\mathrm{a}}$ & $39.22 \pm 0.10^{\mathrm{a}}$ \\
\hline \multicolumn{2}{|c|}{ L.S.D ${ }_{0.05}$} & 0.57 & 1.56 & 0.82 & 0.47 & 3.13 & 1.34 \\
\hline
\end{tabular}


These results are comparable to Olaoye et al., (2006). Also Vásquez et al., (2016) reported that wheat flour was partially substituted with sorghum, oat, or corn flours at the levels of 2.5, $5,7.5$, and $10 \%$. These modifications were related to changes in the composition of the dry matter resulting from differences in the properties of substitution cereal components (carbohydrates, proteins, ash and lipids). Hence low substitutions could considerably reduce the cost of raw materials and could nutritionally improve products with cereal blends.

\subsection{Texture Analysis of unleavened flat bread blends}

Data presented in Table (7) showed texture analysis of unleavened bread made from wheat flour (control) and oat or barley flour with different cereals during storage periods at room temperature. The hardness increased during storage period, whereas the lowest value for hardness recorded in unleavened bread (B4 and O4) during storage period compared with control and other bread. Also oat formulas bread recorded the lower values for other parameters (Springiness and Adhesiveness) during storage period compared with the barley samples. These results are probably due to beta- glucans and production of dextrin that had high water absorption. In addition, Ahlborn et al., (2005) stated that, the crumb hardness is major quality factor in baked goods, as it is strongly associated with consumers' perception of bread freshness. The results were in agreement with Sobczylc (2008) who reported that hardness, is an important trait determining the storage time of confectionery and bread. Also Malik et al., (2015) reported that the hardness increased in the multigrain bread samples with the increase of the fiber content. The springiness (elasticity) of the bread samples decreased with the increase in the fiber content, less the amount of composite flours, more desirable is the chewiness.

3.5.Total bacterial count content of unleavened flat bread blends during storage periods

The content of total count for barley and oat blends bread was presented in Table 8 .

The total count (total aerobic mesophilic bacterial count $(\log \mathrm{cfu} / \mathrm{g})$ ranged from $2.5 \pm$ 0.05 to $2.75 \pm 0.14$ for formula $\mathrm{O} 4(60 \%$ oat +20 $\%$ wheat $+10 \%$ rice $+5 \%$ corn $+5 \%$ sorghum)

Table (7): Texture analysis of unleavened flat bread blends during storage periods at room temperature.

\begin{tabular}{|c|c|c|c|c|c|c|c|c|c|c|}
\hline \multirow{2}{*}{$\begin{array}{l}\text { Flat bread } \\
\text { Parameters }\end{array}$} & \multirow{2}{*}{$\begin{array}{l}\text { Storage } \\
\text { period }\end{array}$} & \multirow{2}{*}{$\begin{array}{c}\text { Control } \\
\text { (Wheat } \\
82 \%) \\
\end{array}$} & \multicolumn{4}{|c|}{ Barley Samples } & \multicolumn{4}{|c|}{ Oat Samples } \\
\hline & & & B1 & B2 & B3 & B4 & 01 & $\mathbf{O 2}$ & $\mathbf{O 3}$ & $\mathbf{0 4}$ \\
\hline \multirow{3}{*}{$\begin{array}{l}\text { Hardness } \\
(\mathrm{N})\end{array}$} & Zero & 6.14 & 6.74 & 6.52 & 6.1 & 5.45 & 11.05 & 7.53 & 7.1 & 6.49 \\
\hline & $24 h$ & 7.14 & 7.96 & 7.28 & 7.6 & 6.94 & 11.76 & 8.53 & 8.66 & 7.6 \\
\hline & $48 \mathrm{~h}$ & 9.29 & 11.65 & 10.95 & 9.21 & 7.12 & 14.26 & 11.05 & 9.71 & 7.78 \\
\hline \multirow{3}{*}{$\begin{array}{c}\text { Springiness } \\
(\mathrm{mm})\end{array}$} & Zero & 2.42 & 1.64 & 1.79 & 2.07 & 2.07 & 1.56 & 1.76 & 1.99 & 2.01 \\
\hline & $24 h$ & 1.26 & 1.36 & 1.52 & 1.61 & 1.84 & 1.16 & 1.52 & 1.83 & 1.83 \\
\hline & $48 \mathrm{~h}$ & 1.22 & 1.15 & 1.29 & 1.48 & 1.76 & 0.94 & 1.16 & 1.25 & 1.37 \\
\hline \multirow{3}{*}{ Adhesiveness } & Zero & 0.20 & 0.20 & 0.20 & 0.20 & 0.20 & 0.20 & 0.10 & 0.10 & 0.10 \\
\hline & $24 h$ & 0.40 & 0.20 & 0.30 & 0.30 & 0.20 & 0.20 & 0.20 & 0.10 & 0.10 \\
\hline & $48 \mathrm{~h}$ & 0.50 & 0.30 & 0.40 & 0.40 & 0.40 & 0.50 & 0.20 & 0.20 & 0.30 \\
\hline \multirow{3}{*}{ Resilience } & Zero & 0.03 & 0.04 & 0.02 & 0.03 & 0.04 & 0.04 & 0.02 & 0.03 & 0.05 \\
\hline & $24 \mathrm{~h}$ & 0.05 & 0.05 & 0.02 & 0.04 & 0.04 & 0.05 & 0.03 & 0.04 & 0.05 \\
\hline & $48 \mathrm{~h}$ & 0.11 & 0.05 & 0.05 & 0.09 & 0.05 & 0.10 & 0.05 & 0.07 & 0.08 \\
\hline
\end{tabular}

Table (8): Total bacterial count content (log CFU/g) of unleavened flat bread blends during storage periods .

\begin{tabular}{|c|c|c|c|c|}
\hline Sample $(\log$ CFU/g) & Zero time & $\mathbf{2 4} \mathbf{h}$ & $\mathbf{4 8 h}$ & $\mathbf{7 2 h}^{\mathrm{h}}$ \\
\hline Control & 0.0 & $2.75 \pm 0.14^{\mathrm{a}}$ & $3.75 \pm 0.14^{\mathrm{a}}$ & $5.25 \pm 0.14^{\mathrm{a}}$ \\
\hline B3 & 0.0 & $2.70 \pm 0.00^{\mathrm{a}}$ & $3.00 \pm 0.00^{\mathrm{a}}$ & $5.00 \pm 0.00^{\mathrm{a}}$ \\
\hline B4 & 0.0 & $2.55 \pm 0.02^{\mathrm{a}}$ & $2.90 \pm 0.05^{\mathrm{a}}$ & $4.25 \pm 0.14^{\mathrm{ab}}$ \\
\hline O3 & 0.0 & $2.70 \pm 0.00^{\mathrm{a}}$ & $2.95 \pm 0.08^{\mathrm{a}}$ & $4.75 \pm 0.14^{\mathrm{ab}}$ \\
\hline O4 $_{\text {L.S.D }}^{\mathbf{0 . 0 5}}$ & 0.0 & $2.50 \pm 0.05^{\mathrm{ab}}$ & $2.85 \pm 0.08^{\mathrm{ab}}$ & $4.20 \pm 0.11^{\mathrm{ab}}$ \\
\hline
\end{tabular}

Means in the same column with different letters are significantly different $(p \leq 0.05)$

Each mean value is followed by $\pm \mathrm{SE}$ (standard error) 
and control sample, respectively after $24 \mathrm{hr}$ storage period. While the highest total count were found in control bread $(5.25 \pm 0.14)$ at the end of storage period $(72 \mathrm{hr})$. Also the formulas (O4 and B4) bread recorded the lowest value at the end of storage period $(72 \mathrm{hr})(4.2 \pm 0.11 ; 4.25$ \pm 0.14 , respectively), this may be due to their content of beta- glucan component as adsorbed water free and low water activity content due to decrease bacterial activity and presence antibacterial agent in multigrain brans ( Chamidah et al., 2017).

\subsection{Yeast count content of unleavened flat bread blends during storage periods}

The content of yeast count for barley and oat bread blends were presented in Table (9).

The yeast count $(\log \mathrm{cfu} / \mathrm{g})$ ranged from $2.20 \pm 0.00$ to $2.55 \pm 0.02$ for formula $(\mathrm{O} 4)$ and acceptable; $10^{4}-10^{5}$ are tolerable and; however, above $10^{5}$ is unacceptable. According to this guideline, the flat bread are in safe range for consumption for three days regardless of the treatment methods and storage period.

\section{Conclusion}

Cereals being the stable diet all over the world need to be utilized in the best possible combination to cater to the health requirements on daily basis. In the concept of multigrain products, in this investigation, the results obtained revealed that flat bread prepared from multigrain mix with fenugreek powder were found to be nutritionally superior to ordinary bread. Multigrain bread would serve as functional food because of its high fiber content while wheat flour only is a poor source of fibers, which are very important components of human

Table (9): Yeast count content $(\log \mathrm{CFU} / \mathrm{g})$ of unleavened flat bread blends during storage periods.

\begin{tabular}{|c|c|c|c|c|}
\hline Sample $(\log$ CFU/g) & Zero time & $\mathbf{2 4} \mathbf{~ h}$ & $\mathbf{4 8 h}$ & $\mathbf{7 2 h}^{\mathrm{h}}$ \\
\hline Cont & 0.0 & $2.45 \pm 0.02^{\mathrm{a}}$ & $3.25 \pm 0.14^{\mathrm{a}}$ & $4.75 \pm 0.14^{\mathrm{a}}$ \\
\hline B3 & 0.0 & $2.55 \pm 0.02^{\mathrm{a}}$ & $2.70 \pm 0.00^{\mathrm{a}}$ & $4.25 \pm 0.14^{\mathrm{a}}$ \\
\hline B4 & 0.0 & $2.30 \pm 0.05^{\mathrm{ab}}$ & $2.70 \pm 0.05^{\mathrm{a}}$ & $4.10 \pm 0.05^{\mathrm{a}}$ \\
\hline O3 & 0.0 & $2.35 \pm 0.02^{\mathrm{a}}$ & $2.60 \pm 0.05^{\mathrm{a}}$ & $4.00 \pm 0.00^{\mathrm{a}}$ \\
\hline O4 $_{\text {L.S.D }}^{\mathbf{0 . 0 5}}$ & 0.0 & $2.20 \pm 0.00^{\mathrm{ab}}$ & $2.45 \pm 0.02^{\mathrm{b}}$ & $3.90 \pm 0.05^{\mathrm{ab}}$ \\
\hline
\end{tabular}

Means in the same column with different letters are significantly different $(p \leq 0.05)$

Each mean value is followed by $\pm \mathrm{SE}$ (standard error)

for formula (B3), respectively after $24 \mathrm{hr}$ storage period. While the highest yeast count were found in control bread $(4.75 \pm 0.14)$ at the end of storage period $(72 \mathrm{hr}$ ). Also the formulas (B4 and $\mathrm{O} 4)$ recorded the lowest value at the end of storage period $(72 \mathrm{hr})(4.10 \pm 0.05 ; 3.90 \pm 0.05)$ respectively, this may be due to the content of beta- glucan or components as antimicrobial agent. Ho et al., (2014) reported that population of aerobic plate counts; mould and yeast count was observed increasing with the time of storage. Also, Dereje and Beruk, (2017) reported that the microbial load mean scores showed that there was no significant difference due to the treatments effect on the microbial loads. The microbial load increased as the storage time increased. Guidelines for ready-to-eat food of department of medical sciences, ministry of public health, Thailand, define that yeasts per gram must be less than 10,000 (less than $4 \log$ $\mathrm{cfu} / \mathrm{g}$ ) and molds/g must be less than 500 (less than $2.7 \log \mathrm{cfu} / \mathrm{g}$ ). According to this guideline, the flat bread are in safe range for consumption for three days for yeast and mold. According to Olaoye et al., (2006), ready-to-eat foods with total bacterial count between $0-10^{3}$ are diets. It can also be concluded that the use of multigrain mix up to high levels as partial replacement of wheat flour can be considered for the production of bread with perceptible taste of multi-grains, good acceptability, higher nutritional value and also increased shelf life quality. Finally it could be stated that, Multigrain flour has an increasing interest as they are important ingredients in the food industry such as functional and healthy foods formulations as biscuits, breads, and cakes.

\section{REFERENCES}

Abdelaal H.S.A. and Thilmany D.(2019). Grains production prospects and long run food security in Egypt. Sustainability,11:44574474. http://dx. doi: 10.3390/Su11164457

Abdelghafor R.F., Mustafa A.I., Ibrahim A.M.H. and Krishnan P.G. (2011). Quality of

bread from composite flour of sorghum and hard white winter wheat. Adv. J.

Food Sci. Tech., 3(1): 9-15.

Abulude F.O. (2005): Distribution of selected minerals in some Nigerian white bread. Nigerian Food J., 23: 139-147.

Ahlborn G. J., Pike O. A., Hendrix S. B., Hess 
W. M. and Huber C.S. (2005). Sensory, mechanical and microscopic evaluation of staling in low-protein and gluten-free breads. Cereal Chem., 82(3): 328-335.

Al-Dmoor H.M. (2012). Flat bread: ingredients and fortification. Quality Assurance and Safety of Crops \& Foods, 4:2-8. http://dx.doi.org/10.1111/j.1757837X.2011.00121.X

Ameh M.O., Gernah D.I. and Igbabul B.D. (2013). Physico-chemical and sensory evaluation of wheat bread supplemented with stabilized undefatted rice bran. Food Nut. Sci., 4: 43-48. http://dx.doi.org/10.4236/fns.2013.49A2007

Angioloni A. and Collar A.C. (2011). Polyphenol composition and "in- vitro" antiradical activity of single and multigrain breads. J. Cereal Sci., 53: 90-96.

Anonymous (2011). (www. ifood. tv/ network/ multigrain bread; Multigrain breadCulinary Encyclopedia). Accessed 14 December 2011.

AOAC (2005). Official Methods of Analysis of the Association of Official Analytical Chemists. $18^{\text {th }}$ Edition, Washington DC.USA

Belobrajdic D. K. and Bird A. R. (2013). The potential role of phytochemicals in whole grain cereals for the prevention of type- 2 diabetes. Nut. J., 12:62

Cavazos A. and Gonzalez de Mejia E. (2013). Identification of bioactive peptides from cereal storage proteins and their potential role in prevention of chronic diseases. Compr. Rev. in Food Sci. Food Safety, 12: 364-380.

Chamidah A., Hardoko H. and Prihanto A. A. (2017). Antibacterial activities of $\beta$-glucan (Laminaran) against gram- negative and gram- positive bacteria. The $7^{\text {th }}$ International conference on global resource conservation AIP Conf. Proc. 1844, 020011-1- o20011-7; http://dx.doi: 10.1063/1.4983422

Chávez D. W. H.,Ascheri J. L. R.,Carvalho C. W. P., Godoy R. L. D. and Pacheco S. (2017). Sorghum and roasted coffee blends as a novel extruded product: Bioactive compounds and antioxidant capacity.J.Func. Foods, 29: 93-103.

http://dx.doi.org/10.1016/j. jff.2016.12.012.

Cho S., Yoon S. H., Min J., Lee S., Tokar S.- O. L. and Seo H.-S. (2014). Sensory characteristics of seolgitteok (Korean rice cake) in relation to the added levels of brown rice flour and sugar. J. Sensory Studies, 29 (5): 371-383.

Coskuner Y., Karababa E. and Ercan R. (1999). Flat Bread Production Technology. The J. Food, 24: 83-97.

De Cardoso L.M., Pinheiro S.S., da Silva L.L., de Menezes C.B., de Carvalho C.W., Tardin F.D., Queiroz V.A., Martino H.S. and Pinheiro-Sant'Ana H.M.(2015). Tocochromanols and carotenoids in sorghum (Sorghum bicolor L.): Diversity and stability to the heat treatment. Food Chem., 172: 900-908.

Dereje G.B. and Beruk B.D. (2017). Formulation of Flat Bread (Kitta) from Maize (Zea Mays Linaeus.) and Amaranth (Amaranthus Caudatus L.): Evaluation of Physico-Chemical Properties, Nutritional, Sensory and Keeping Quality. International J. Food Sci. Nutr. Engin., 7(6): 125-131. http://dx.doi.org/10.5923/j.food.20170706.01

De Vuyst L. and Vancanneyt M. (2007). Biodiversity and identification of sourdough lactic acid bacteria. Food Microbiol., 24: 120-127.

Dewettinck K., Van Bakstaele F., Kuhne B., Walle V., Courtens T. and Gellynck X. (2008). Nutritional value of bread: Influence of processing food interaction and consumer perception. Rev. J. Cereal Sci., 48: 243-257. http://dx.doi.org/10.1016/j.jcs.2008.01.003

Dhingra D., Michael M., Rajput H. and Patil R. T. (2012). Dietary fibre in foods: a review. J. Food Sci. Tech., 49 (3):255-266.

Dhingra S. and Jood S. (2004). Effect of Flour Blending on Functional, Baking and Organoleptic Characteristics of Bread. Int'1 J. Food Sci. Tech. 39: 213-222.

Dhore K.R. (2011). Sensory Evaluation of Sorghum Chakali Enriched with Different Levels of Soya bean Flours. Int'l Refer. Res. J., 3: 50-51.

Dykes L. and Rooney L.W. (2007). Phenolic compounds in cereal grains and their health benefits. Cereal Foods World, 52 (3): 105111.

http://dx.doi.org/10.1094/CFW-52-3-0105

FAO. (1995). Sorghum and Millets in Human Nutrition; FAO Food and Nutrition Series, No. 27; FAO: Rome, Italy, 1995.

FAOSTAT (2014). FAOSTAT Databases. Available online: http://faostat3.fao.org (access on 22 September 2014).

Gomez M., Ronda F., Coballera A. P., Blanco 
A.C. and Rosell C.M.(2007). Functionality of different hydrocolloids on the quality and shelf life of yellow layer cakes. Food Hydrocoll., 21(2): 167-173.

Gonzales-galan A., Wang S.H., Sgarbieri V. C. and Moraes M.A.C. (1991). Sensory and nutritional properties of cookies based on wheat- rice-soybean flours baked in microwave oven. J. Food Sci., 65 (6): 16991701.

Gül H., Ozcelik O. S. and Certel M. (2005). Sourdough bread production with Lactobacilli and S. cerevisiae isolated from sourdoughs. Process Biochem., 40:891-697.

Gupta M., Bawa A.S. and Semwal A.D. (2011). Effect of Barley Flour Blending on Functional, Baking and Organoleptic Characteristics of High-Fiber Rusks. J. Food Process. Preserv., 35: 46-63.

Han W., Ma S., Li L. Wang X.-X. and Zheng X.-L. (2017). Application and development prospects of dietary fibers in flour products. J. Chem., 3: 1- 8. http://dx.doi: 10.1155/2017/2163218

Henley E.C. (2010). Sorghum: An Ancient, Healthy and Nutritious Old World Cereal; JPZ Consulting Group: St. Louis, MI, USA.

Hidalgo A., Scuppa S. and Brandolini A. (2016). Technological quality and chemical composition of puffed grains from einkorn (Triticum monococcum L. subsp. monococcum) and bread wheat (Triticum aestivum L. subsp. aestivum). LWT - Food Sci. Tech., 68: 541-548. http://dx.doi.org/10.1002/jsfa.6382

Ho L. H., Abdul Aziz N. A., Bhat R. and Azhari B. (2014). Storage studies of bread prepared by incorporation of the banana pseudo-stem flour and the composite breads containing hydrocolloids. CYTA- J. Food, 12(2): 141- 149.

Jones J.M. (2006). Grain-based foods and health. Cereal Foods World, 5 (3): 108-113.

Krivanek A.F., De Groote H., Gunaratna N., Diallo A. and Friesen D. (2007). Breeding and disseminating quality protein maize (QPM) for Africa. Afr. J. Biotech., 6: 312324.

Land D.G. and Shepherd R. (1988). Scaling and Ranking Methods. In: "Sensory Analysis of Foods" Piggott, J.R., (Ed.),Elsevier Applied Sci., London,UK., 155-185.

Lieu P.T., Heiskala M., Peterswon P.A. and Yang Y. (2001). The roles of iron in health and disease. Mol. Aspects Med., 22(1-2): 187.

Malik H., Gulzar A. N. and Dar B.N. (2015). Optimization of Process for Development of Nutritionally Enriched Multigrain Bread. J. Food Process. Technol,7(1):544-549. http://dx.doi.org/10.4172/2157-7110.1000544

Malolma S. A., Eleyinmi A. F. and Fashankin J.B. (2011). Chemical composition, rheological properties and bread making potential of composite flours from bread fruit, bread nut and wheat. Afr. J. Food Sci. 5: 400-410.

Marchetti L., Cardós M., Campaña L. and Ferrero C. (2012) Effect of glutens of different quality on dough characteristics and bread making performance. LWT-Food Sci. Tech., 46: 224-231. http://dx.doi.org/10.1016/j.lwt.2011.10.002

Mattila P., Pihlava J.M. and Hellstrom J. (2005). Contents of phenolic acids, alkyl- and alkenylresorcinols, and avenanthramides in commercial grain products. J. Agric. Food Chem. 53: 8290-8295. http://dx.doi.org/10.1021/jf051437z; PMid:16218677

Maxwell S. E. and Delaney H.D. (1989). Designing experiments and analyzing data. Wads Worth Publ.Com.Belmont CA.,USA.

Mondal A. and Datta A.K. (2008). Bread Baking-A Rev. J. Food Eng., 86: 465-476. http://dx.doi.org/10.1016/j.jfoodeng.2007.11.014

Nammakuna N., Barringer S. A. and Ratanatriwong P. (2016). The effect protein isolates and hydrocolloids complexes on dough rheology, physicochemical properties and qualities' of gluten- free crackers. Food Sci. Nut., 4(2): 143-155.

Olaoye O. A., Onilude A.A. and Idowu O.A. (2006). Quality characteristics of bread produced from composite flours of wheat, plantain and soybeans. Afr. J. Biotech. 11: 1102-1106.

Puntarulo S. (2005). Iron, oxidative stress and human health. Mol. Aspects Med., 26: 299312.

Salazar-López N. J., Gustavo G., Dfelia R. and Maribel R. (2017). Technologies applied to sorghum (Sorghum bicolor L. Moench): changes in phenolic compounds and antioxidant capacity. Food Sci. Technol., Campinas, 38(3): $369-382$. https://doi.org/10.1590/fst.16017

Sanful R. E. and Darko S. (2010). Production of Cocoyam, Cassava and Wheat Flour 
Composite Rock Cake.Pak. J. Nutr.9:810814.

Sharma S., Sekhon K.S. and Nagi H.P.S. (1995). Sensory Characteristics and Storage Quality of Flat Bread from Indian Wheats. Chemie Mikrobiologie Technologie der Lebensmittel, 17: 156-160.

Shalini K. G. and Laxmi A. (2007): Influence of additives on rheological characteristics of whole-wheat dough and quality of Chapatti. (Indian unleavened flat bread) part Ihydrocolloids. Food Hydrocoll., 21: 110117.

Shobha V., Kasturiba B., Naik R. K. and Yenagi N. (2008). Nutritive Value and Quality Characteristics of Sorghum Genotypes. Karnataka J. Agric. Sci., 20: 586-588.

Shubhangini, A.J. (2002). Nutrition and Dietetics. $2^{\text {nd }}$ Edition, Tata Mc Graw-Hill Publishing Co. Ltd., New Delhi, India.

Sirichokworrakit S., Phetkhut J. and Khommoon A. (2015). Effect of partial substitution of wheat flour with rice berry flour on quality of noodles. Proc.-Soc. and Behav. Sci., 197: 1006-1012.

Sobczylc M. (2008). Effect of various oat forms on quality of confectionery. Polish j. Food Nutria. Sci., 58(3):301-305.
Srivastava A.K., Meyer D., Rao H. P. and Seibel W. (2002). Scanning Electron Microscopic Study of Dough and Chapatti from glutenReconstituted Good and Poor Quality Flours. J. Cereal Sci., 35: 119-128. http://dx.doi.org/10.1006/jers.2001.0432

U.S.D.H.S and U.S.D.A. (2005). United States Department of Health and Human Services and United States Department of Agriculture. Dietary Guidelines for Americans2005.Washington, DC.

http://www.health.gov/dietaryguidelines/dg a2005/document/pdf/DGA2005.pdf

Vásquez F., Samuel V., Alma R. I., José M. B. and Raúl G. (2016). Effect of low degrees of substitution in wheat flour with sorghum, oat or corn flours on physicochemical properties of composite flours. Cogent Food \& Agric., 2:979-990. http://dx.doi.org/10.1080/23311932.2016.126997

Wani A.I., Singh D.S., Sharam P. and Singh B.G. (2016). Physicochemical and pasting properties of unleavened wheat flat bread (Chapatti) as affected by addition of pulse flour. Cogent Food \&Agric., 2:1-9. http://dx.doi.org/10.1080/23311932.2015.1124486 Year Book of Agriculture statistics (2016). Ministry of Agriculture and Land Reclamation, Egypt.

\section{الإستفادة من بدائل القمح فى انتاج خبز مسطح عالى القيمة الغذائية
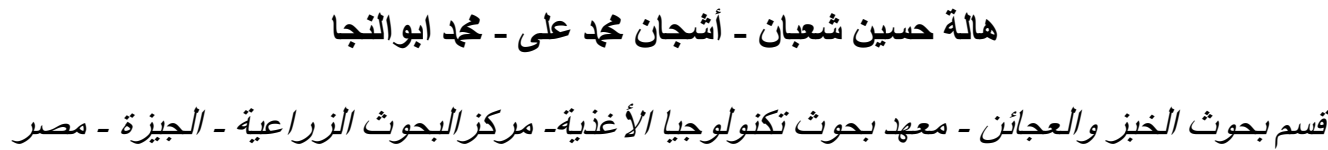

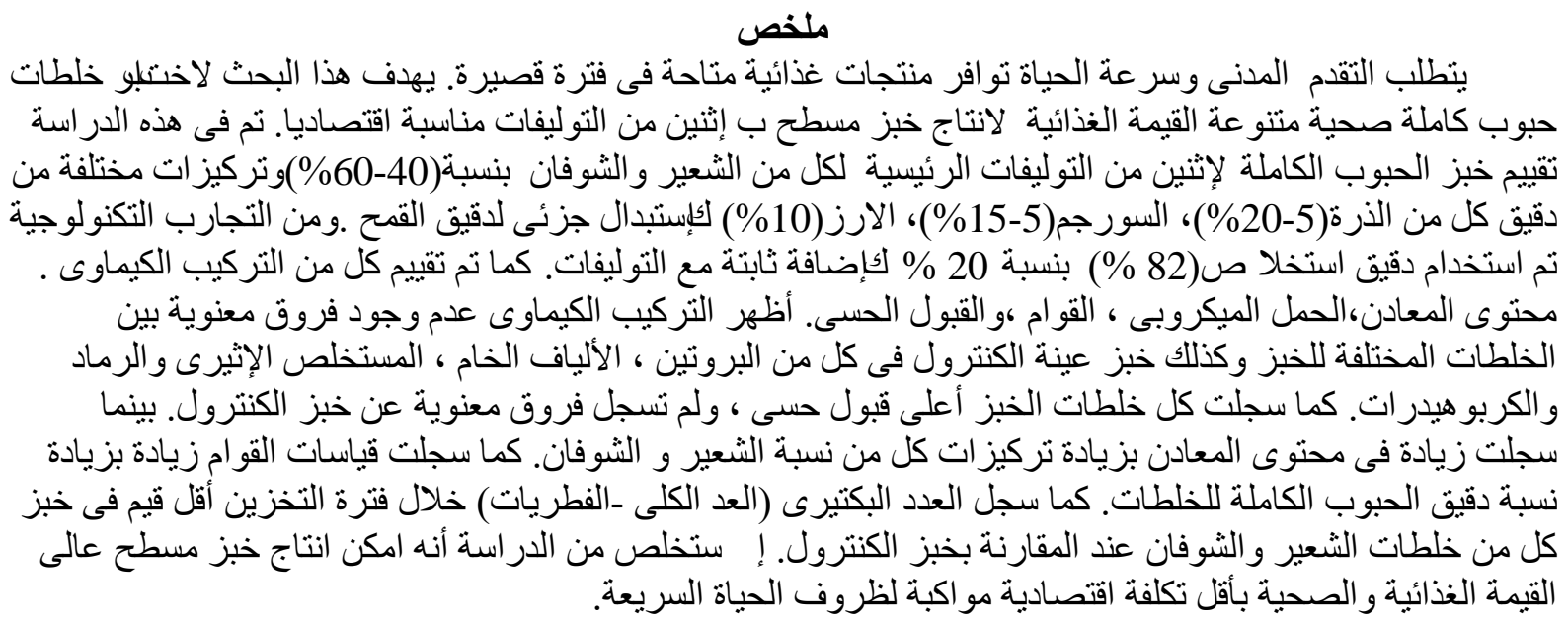

المجلة العلمية لكلية الزراعة - جامعة القاهرة ـ المجلد (71) العدد الثالث (يوليو 2020): 146-156 ـ 


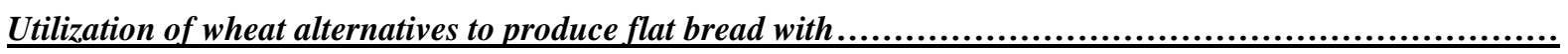

